草生ならびに資材被轁によるチャの裂傷型凍害の防止法

\author{
马家昭一**岡本信義**. 檤口義剛*1 \\ 獄 崎 亮**. 徳永保利*2 . 大城光高**
}

\title{
Preventive Methods for the Bark Splitting Injury to Young Tea Plants with Covering Grasses and Materials
}

\author{
By Shoichi YUGE*, Nobuyoshi OKamoto**, Yoshitaka HiguCHI*, \\ Ryo TAKESAKI**, Yasutoshi ToKUnAGA*, and Mitsutaka OHKI**
}

\section{1 まえがき}

チャの幼木の地際部にみられる裂傷型凍害は，温暖地 ほど䫓著な実態がある。このことは，その症状が現かれ る前後の季節における他の地域との気皇要因等の微妙な 環境差飞基づくものと思われる面と，今一つには暖地向 として普及された品程の耐谏性等にも問題の起团する条 件があったのではないかと若えられる。

徒って，この裂傷型凍害防止技術の一方法としては， 酎凍性獲得の条件を 茶栽培場面での微気象制御の簡易な 方法として確立することが当面の対応策として急務であ った。

本報告は，耐凍性の弱い品種を供試して，草生法や資
材被覆法の效果を裂賃型凍害研究会での研究の一環とし て宮崎，鹿児息両県の共同試験（1973～1975年）で实施 榆討した成果の概要である。

\section{2 試 験 方 法}

\section{1 草生被覆法}

宮崎では，1973年 は草種，は種量，は種期，1974〜19 75年にはは種量，は種期，刈り込みの有無について実施 した。また1975年には現地試験（2 ケ所）も行った。鹿 垐島では草種，は種位置（1973年）について実施した。

\section{2 資材被覆法}

宫崎では，1973〜1975年を通じ資材の種類，被㠅法に ついて主としてトンネル被澓法により行い，1975年は現

表1 草生法 (宮崎)

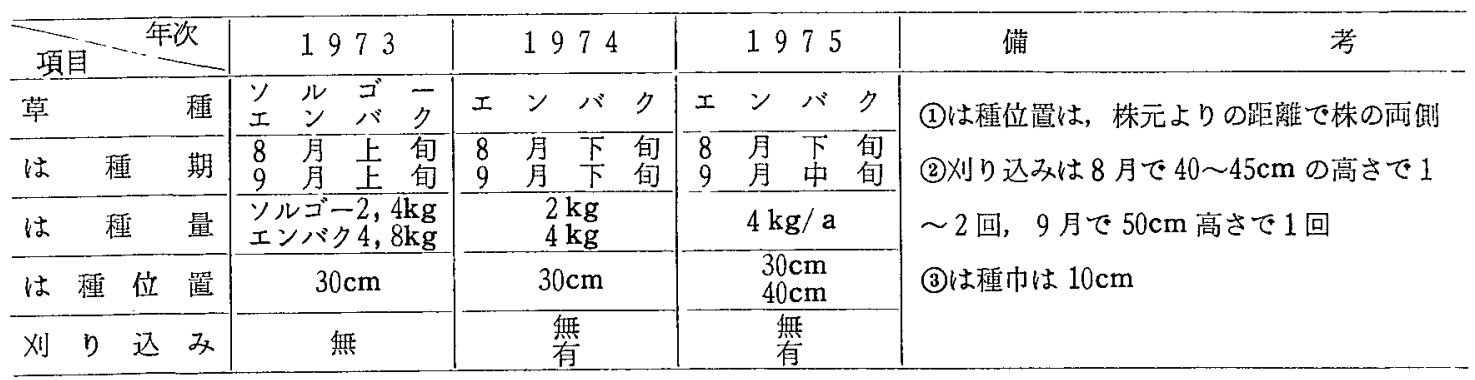

注：1）供試品種：や兄活ゆたかみどり

2）栽植条件：畦間 $150 \mathrm{~cm} ，$ 株間 $30 \mathrm{~cm}$ ，単条

* 宦崎県総合農業試験場茶業支場

$\left(\begin{array}{ll}* 1 & \text { 現 } \text { 宮崎県高鍋農業改良普及所 } \\ * 2 & \text { 現 宫崎県農政水産部営農指導課 }\end{array}\right)$

Tea Branch, Miyazaki Agricultural Experiment Station

** 鹿垐島県茶業試験場

Kagoshima Prefecture Tea Experiment Station 
表2 資 材 処理 法（宮 崎）

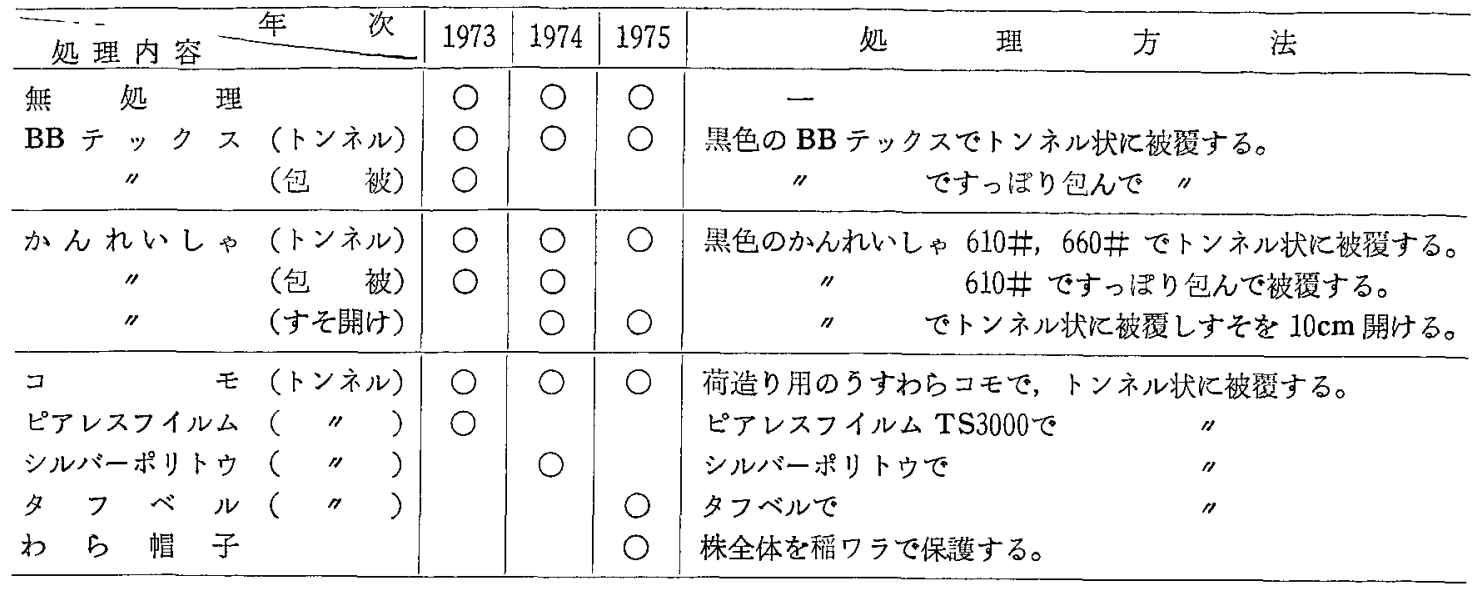

注：1）処 理 日 1973年:10月29日 1974年：11月 5 日 1975年：10月27日

2) 処理状沉

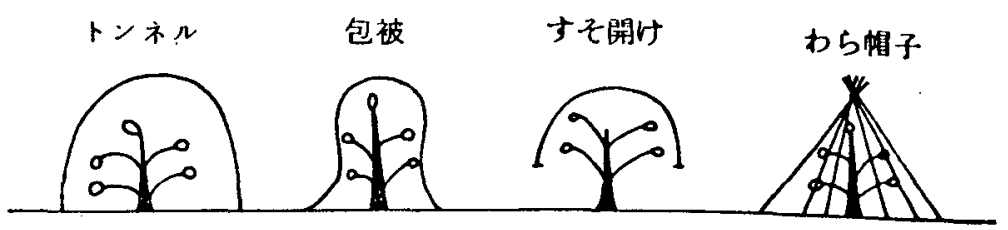

3）供試品種や它漂，ゆたかみどり

4）载植条件哇間 $150 \mathrm{~cm}$ ，株間 $30 \mathrm{~cm}$ ，単条

地武験も実施した。なた鹿児舄では 1974〜1975年にうね の南側 $30 \mathrm{~cm}$ のところに高さ $90 \mathrm{~cm}$ に垂直にネットを張 つて行った。

調查方法は, 最高, 最低気温はルサフォード型温度計 を処理区の中央部の株の地際部に設置し、日射量は口ビ ッチ日射計にて株間の高さ $15 \mathrm{~cm}$ の位置で測定した。土 壤水分は直管式テンシオメータにて，株元より $15 \mathrm{~cm}$ 離 れた深さ $10 \mathrm{~cm}$ の部位を測定した。また，裂傷型凍害は 裂傷が発生したるのについて肉眼観察しその被害率を調 查した。

\section{3 試 験 結 果}

\section{1 裂傷型凍害発生率の差異}

3. 1.1 試験期間の秋冬季気彖の年次变動と裂傷 型凍害の品種間差㟟

1973 1975年 試験期間の川南（宮崎県韭湯郡川南町） 知临 (鹿児島県川辺郡知筧町) 雨試駼地比打万秋冬季 気象の年次別経過は下記のと打りであった。

1973年：気温は川南では9 月以降低めに推移し，順調

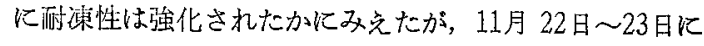
加ての急激な低温 $\left(-2.5 \sim-2.0^{\circ} \mathrm{C}\right)$ と, 続いて 26 日 の低温 $\left(-2.0^{\circ} \mathrm{C}\right)$ により裂賃が発生した。知覧でも同 じような経過を示し，11月 23 日の低温 $\left(-0.1^{\circ} \mathrm{C}\right), 11$ 月 26 日の低温 $\left(0.3^{\circ} \mathrm{C}\right)$ にっって裂㱍が発生した。
〔降水量は，川南の場合 10月中旬までは少なく下旬に多 かったが，11月10日以降 12 月沃がて全然降雨をみな かった。知覧では，10月まで多く経過したが11月は少な く，12月は平年並文であった。

1974 年: 川南の気温は，10月まではやや高めに推移 し，11月には低めに経過したるのの最低気温で $0^{\circ} \mathrm{C}$ 以 下の日はなかった。12月に入り 7 日 $\left(-0.9^{\circ} \mathrm{C}\right)$ と 16 日 $\left(-1.3^{\circ} \mathrm{C}\right)$ の低温に続いて 21 日 $\left(-3.3^{\circ} \mathrm{C}\right)$ 低温で裂 賃が発生した。知覧では，9月以降 12月中旬まで平年並 みかやや高めに推移し，裂傷型凍害の発生しやすい条件 にあったが，初稫に当たる 12 月 16 日の低温 $\left(-0.8^{\circ} \mathrm{C}\right)$ によっては裂傷は発生せず，その後 22 日 $\left(-1.4^{\circ} \mathrm{C}\right)$, 23 日 $\left(0.6^{\circ} \mathrm{C}\right), 26$ 日 $\left(0.7^{\circ} \mathrm{C}\right)$ の低温の繰り返しにより 裂稘が発生した。降水量は川南が 10月は平年より少なく 推移したが，11〜12月にかけては平年並みかやや多い程 度であったのに対し，知筧では 10 月が多く11月は少な く12月は多めに経過した。

1975年：川南の場合 11月中は気温も低好推移して, 11 月 24 日 $\left(-2.7^{\circ} \mathrm{C}\right), 25$ 日 $\left(-1.4^{\circ} \mathrm{C}\right)$ の低温江見唩 われ裂㑺が発生した。また12月に入り 12 日 $\left(-1.9^{\circ} \mathrm{C}\right)$ の低温でも発生した。一方, 知覽では11月中旬までは暧 かく，茶樹の耐㭿性は非常に弱いものと思われたが，11 月下旬の冷兄込み $\left(2.8^{\circ} \mathrm{C}\right)$ によって茶樹の耐凍性は強 化されたものと思われ，その後 12 月中旬以降の低温（一 
$0.8^{\circ} \mathrm{C}$ ) で裂傷の発生はなかった。

この年の降水量は，川南では 10 月は少なく経過したの に対し，11月〜12月にかけては平年より多かった。一 方，知覧の場合は 10月は平年より多く推移したものの， 11月には月の前半に降雨が集中し， 月後半洁乾燥気味で あった。12月は上旬に多く，下旬は少なく経過した。

また，試験期間の川南・知覧両試験地に打ける自然条 件下での裂傷型凍害発生状況の年次経過は下記のと括り であった。

川南：供試した品種は，裂甥型㭿害振抗性極弱のや完 焉，弱のゆたかみどりであった。や之潘は，1973年の場 合 11月22・23日の 2 回発生し合わせて98\%，1974年は若 干低めとなり77\%の発生率であった。なた，1975年は試 験期中の5ちで最も裂賃型凍害の厳しい年で $100 \%$ に近 い発生であった。的たかみどりの裂傷発生は，1973年に は94\%6でったが，1974年には全くみられず，1975年に は $99 \%$ 発生をみた。この上5に年次間差はもちろん，

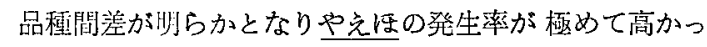
た。

知覽：供試した品種は，少たかみどり，するがわせ， 岂やまみどりであった。1973年の里たかみどりは 81\%の 発生を示し，1974年の場合さやまみどりは 2\%，するが わせは 3\%であったものの1975年には3品種とも全く発 生しなかった。

\section{1.2 草生法による発生防止効果}

図 1 は草生処理と裂傷発生率との関係を示したもので ある。品種による差が大きいが，や克ほでは 1973年の場 合無処理区 $98 \%$ 0発生に対しソルゴー区は $50 \%$ を超党， エンバク区では㤬漂完全们防止できた。1974年は低温の 掯遇が12月中旬に入ってからとなったため，茶樹のハー ドニングが順調炕進んだためか，無処理区の裂䂓発生は 前年に比べると若干低目の 77\%であった。エンバク処理 のうち 9 月下旬は種区が 27〜44\%の裂倠発生をみたが，

8月下旬は種区では 全く発生しなかった。1975年には無 処理区は $100 \%$ に近い発生率をみたのに対してェンバク 草生処理のうち，8月下旬，は種位置 $30 \mathrm{~cm}$ で刈り込ま ない区が裂鹪を完全に防止でき，次いで9月中旬は種位 犆 $20 \mathrm{~cm}$ の刈り込まない区であった。しかし，8月下们 のは種であってもは種位筧を搪げたり, 刈り込み等の処 理は裂儌防止効果を著しく低下させた。一方，ゆたか子 どりでは1973年の場合，両草程とも発生はなく1974年の エンバク処理区でも同様であった。

また1975年の結果は 8 月下旬は種の場合や方活に類似 する傎向をみせ，9月中旬は種区です裂㑺発生を全くみ なかった。この年は都城と南郷の 2 力所で現地試験を行 ったが結果は上記に類似したものの，ただ山䦐高冷地の 場合 8 月下旬は種です平坦地に比べると草丈が不足し, 裂笴防止からすればは種期を早めた方が 安全の上万に思

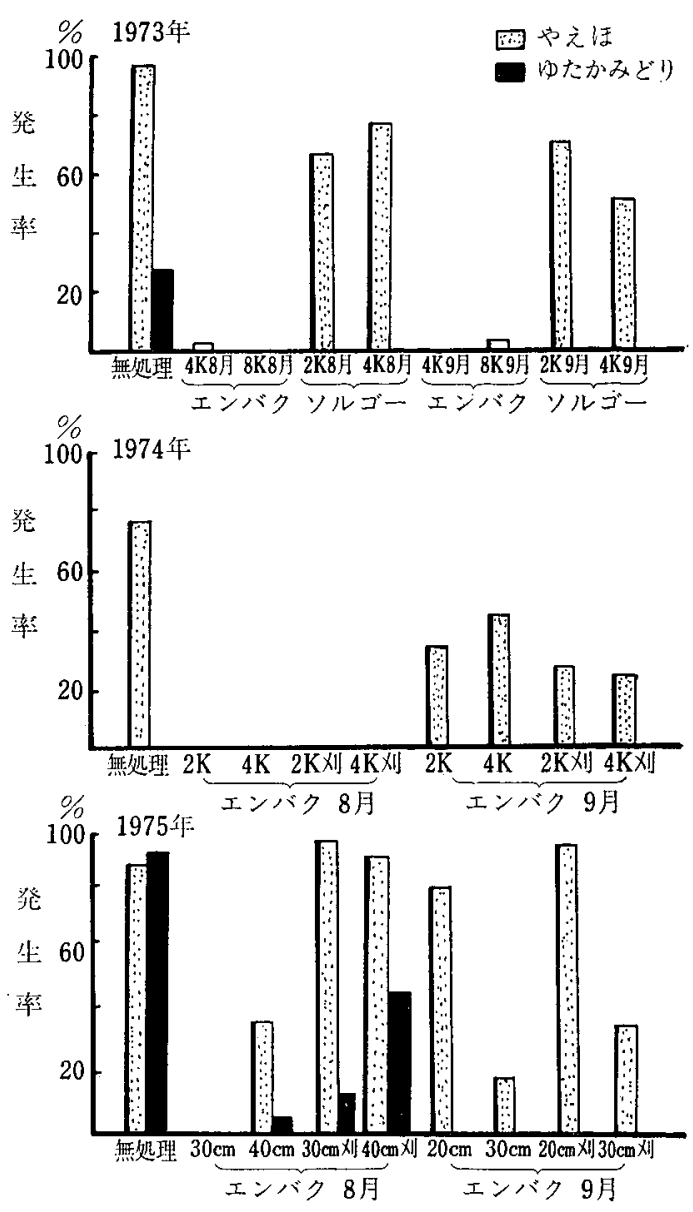

図 1 草生线培と裂復型凍等の発生率 (宮崎)

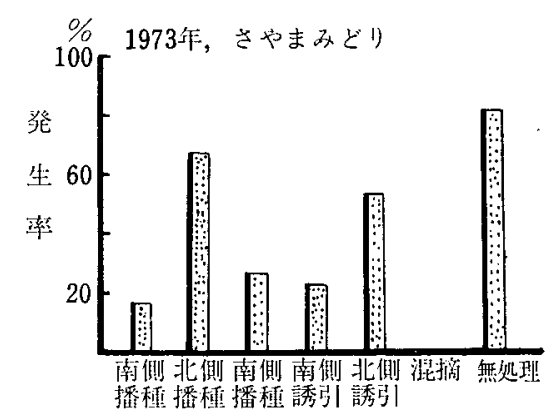

図2 草生栽培と裂傷型凍歚発生率 (庇児島,クロタラリア)

われた。

草種の検討の中で，麇児島萊試のクロタラリア草生の は䨂位置の結果をみると，図2 亿示すと抢り混播区以外 は裂傷型凍害が発生した。すなわち無処理区81\%に対し 北側は程区 $67 \%$ ，北側誘引区 $53 \%$ ，南側は種区 $32 \%$ て あった。この結果からエンバク草生と同様化茶樹全体を 完全に稪ってしまう泥播方法が防止策としては良好であ 


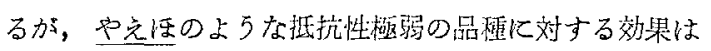
なお不足しているよ5に思われた。

\subsection{3 資材被覆法による発生軽減効果}

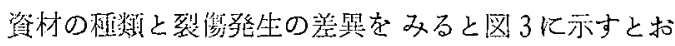

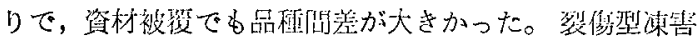

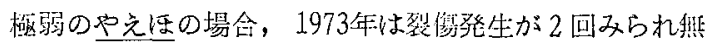
処理区 95\% 亿比しこむ44\%，ピアレス 65\%以外は90\%

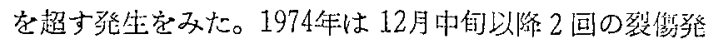
生で然処理区は 5096 と少なく，各凟材処理区ではBBテ ックスとかんれいしゃ \#610が8〜1096発生した以外は

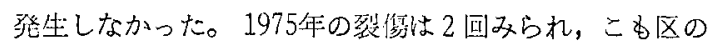
35\%発生以外は全ての資材炕琶区て 95\%以上の登生とな って，これら資材の被㢢效果を超える大発生となった。 抵抗性弱のゆたかみどりの場会には，1973年は然処理で

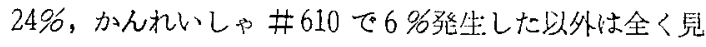
要けられず，1974年では然起理区，好理区ともに癷生は なかった。1975年には凟材被得による效果がみられ，然 処理区 $100 \%$ \%発生に対し，各凟忉とも55\%以下を，そ のなかてこも，タフベル， BBテックスの效果が大きく，
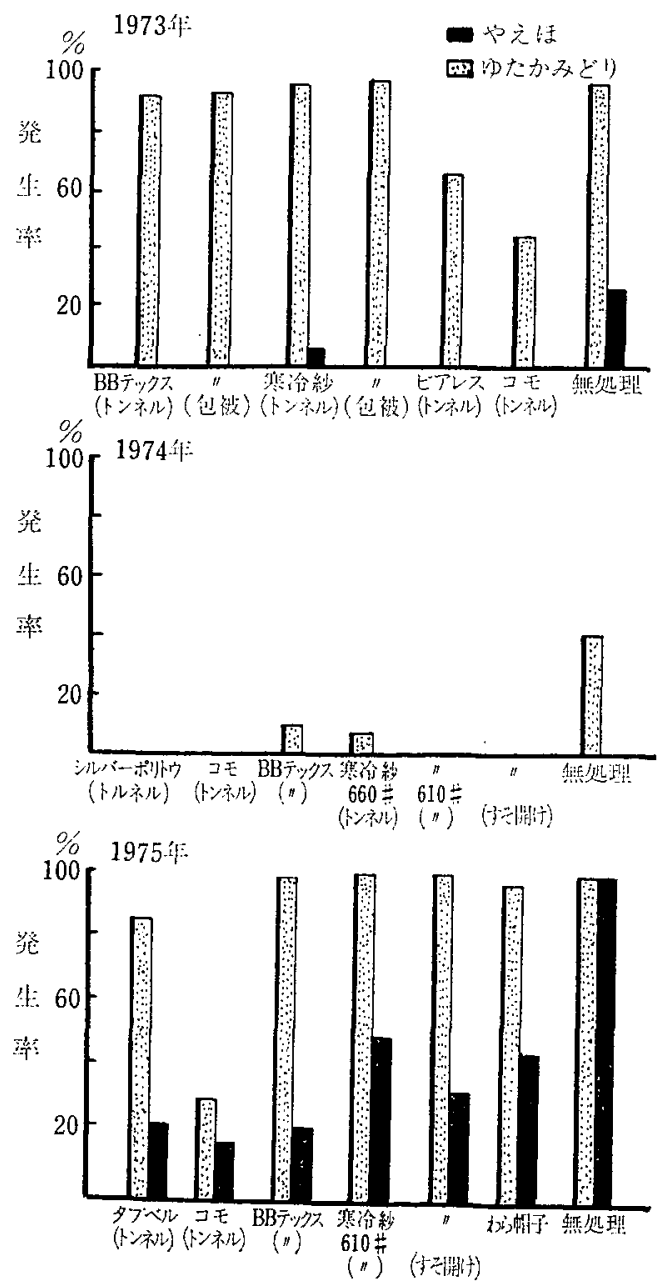

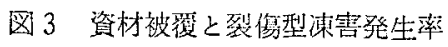

特にこも区の効梨が顛藷であった。な招，1974年に用い たシルバーポリトゥでは，被覆処理中途で落葉を生じ枯 死に烈ったが，このことは完全遮光に近いこの想の資材

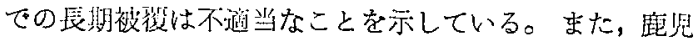

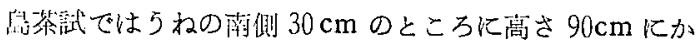
んれいしゃを韭直に張り，遮光程度を变えるために一重 〜三重にした処球について検颜したが，防止効果は低 くやはりトンネル被覆方式がよい結果を得た。

この上5に 1973〜1975年にか㚈て行った草生，ならび

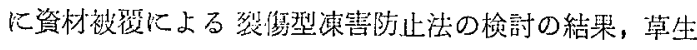
法ではエンバク間作の防止效果が，また被㠅法ではこも

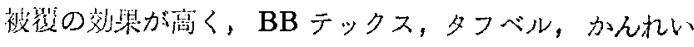
しゃ等の防止效果は、こすに比しやや少ることが認めら れたが，十分活用でるる方法と照われた。

\section{2 草生と資材被覆が株元の気温に及ぼす効果}

\section{2.1 草生法の気温制御}

草生による防止法は，㭃茶樹を被徣保讙し，その保温

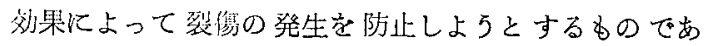
る。各処理区の穴温を舆処理との差で示したすのが図 4 である。1973年の裂傷発生洔の最低気温は無処理より工 ンバク草生区 1.7 4.7 ${ }^{\circ} \mathrm{C}$, ソルゴー区 0.7〜2. $7^{\circ} \mathrm{C}$, 就 ぬに推移し, 雨区の保温勃果は認められたが, ソルゴー 区の効亜は小さかった。これはンルゴー区では初霜前ま ではェンバクと同水準の気温の推移を示したが，初楦に より枯死したためその後は敏処理とそれはど美のない気 温の推格となり、これが裂賃防止效果が劣る結果となっ たものと思われた。1974年をみると8 月は種区 3.5 4.5 ${ }^{\circ} \mathrm{C}, 9$ 月は程区 $3.0 \sim 4.2^{\circ} \mathrm{C}$ とそれぞれ高めに，日較差 では $1.0 \sim 1.7^{\circ} \mathrm{C}$ 小さくなり, 特に 8 月は種区の刈り込 まない場合が最も気温変化が少なかった。また 9 月下旬 は程区では8月は桠に比較し効果が少ったが，これは裂 㑺発生時の草生量の不足により保温がきかなかったため と想われる。1975年にはは種期よりむしろ刈り込みの有 無で差が大きく，8月下旬は種であっても刈り込なない

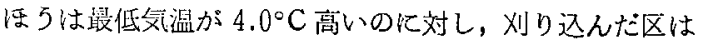
$1.0^{\circ} \mathrm{C}$ 高めになったに過ぎなかった。このことは草生の 埸合幼茶樹を完全に包被する状態であることが必要であ って，9月は種の刚り込みの有無の気温差もこれを装付 けている。

また草生裁坮による裂倁型凍害防止には，最低気温の 洼もさることながら経時的㳇温の推移，すなわち低温持

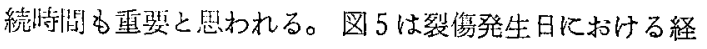
封的な気温の推移を示したものでこれによれば $0^{\circ} \mathrm{C}$ 以下への降下時刻は，無処理の 20時に対し草生处埋では

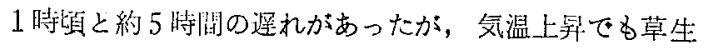
区が早く低温継続将間は短い。さらにうねの方向による 父温较差は，エンバク草生の東西，南北とも8月下旬の $30 \mathrm{~cm}$ 闭側は種であれい゙あまり差はないが，片側は種や 

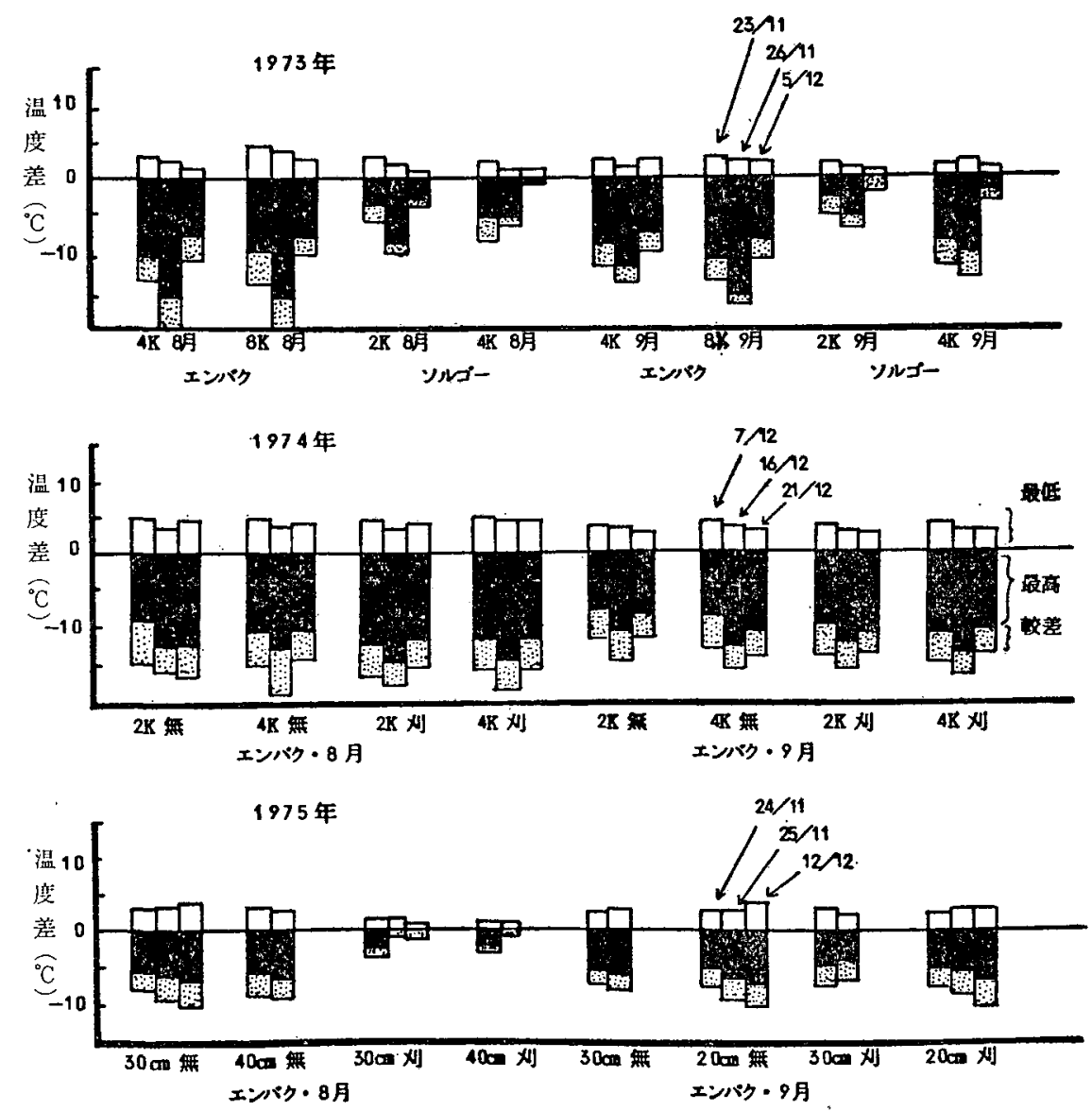

図 4 無処理区に対する, 草生処理区の最高, 最低, 日気温の較差

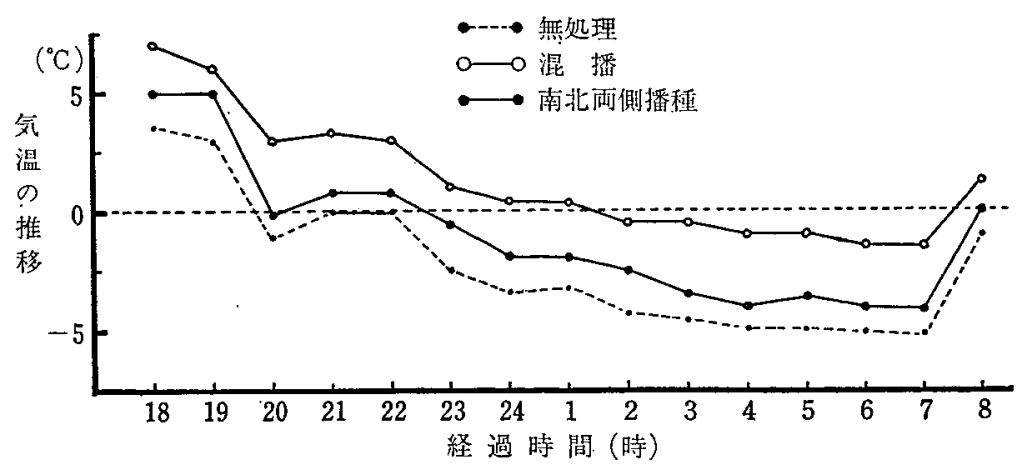

因 5 は種法の違いによる気温の推移（鹿児島，1973年，クロタラリア）

は種位置を抎げたりすると，差す大きくなることが推察 される。

\section{2.2 資材被覆法の気温制御}

資材被㠅法の場合も草生法々同様に，保温效果によ。 て裂傷発生を防止あるいは轻減させようとするるのであ るが，各炕理区の気温を無処理との差で示すと図6の之 おりである。これによると 1973年は無処理区に比べて， こも, BB テックス，ピアレスが $1.4 〜 5.0^{\circ} \mathrm{C}$ それぞれ
高く，日較差も小さくなっていた。1974年には各資材と も最低気温が 1.3〜 $3.0^{\circ} \mathrm{C}$ 高くなり, 特にこすが高く次 いで BBテックス，かんれいしゃトンネルであった。 た 1975年も被覆区の最低気温は $0 \sim 2.5^{\circ} \mathrm{C}$ と高く，なか ではこもが最も高く，BBテックス，タフベルトンネル がこれに次き，かんれいしゃ等は保温効果が認められた が裂䅞防止効果は低いすのなった。一方店児島茶試の かんれいしゃによって奻茶樹の南側から遮光し，日中の 

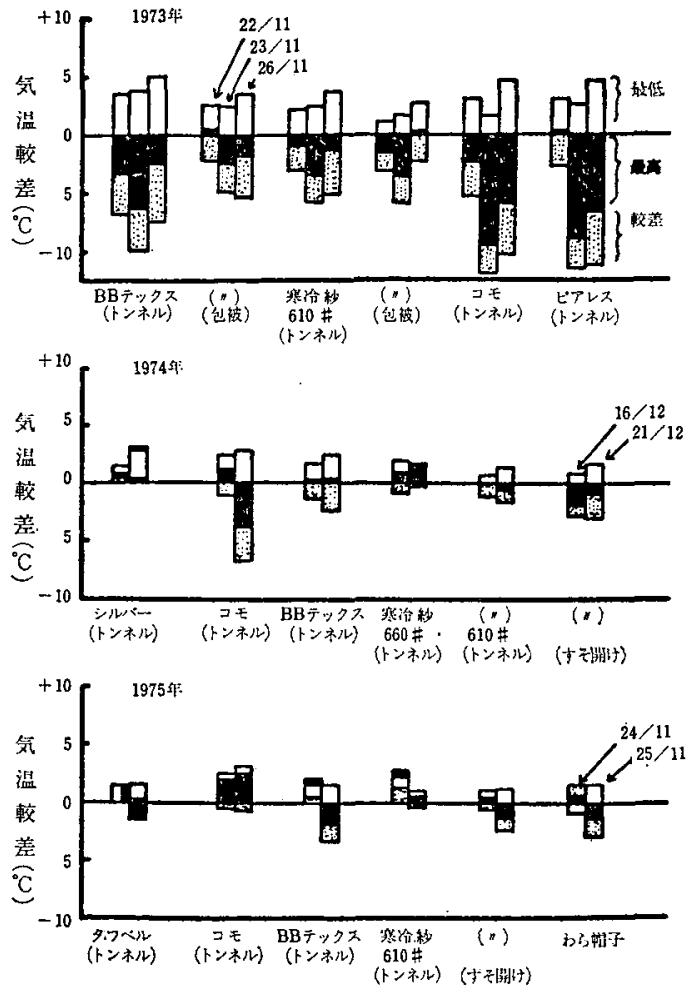

因6 無処理区に対する資材処理区の最高，最低， 日気温の較差

温度を下げて日較差を下げる方法は，日較差は小さくな るが保温効果はなかった。

\section{3 草生の状態による被害発生の差異}

資材によるトンネル被覆の場合，草生に比べると裂傷 発生の軽隇効果は劣る結果となったが, 草生法です草の 被覆状態によって発生に差がみられた。表 4 は1973〜 1975年に拔ける処理別の草生状態を示したものである。

1973 年のエンバク草生の 8 月上旬は種区では 70 80 $\mathrm{cm}, 9$ 月上旬は種区では60 70 cm の草丈で裂傷発生

表 4 草生作物の生育状況 （宮崎）

$$
\text { 一 } 1973 \text { 年一 }
$$

\begin{tabular}{|c|c|c|c|c|}
\hline \multirow{2}{*}{ 処 } & \multirow{2}{*}{ 理 } & \multirow{2}{*}{ 別 } & 草 & 丈 $(\mathrm{cm})$ \\
\hline & & & 11月20日 & 12月 3 日 \\
\hline エンバク & $4 \mathrm{~kg}$ & 8月 & $70 \pm 5$ & $80 \pm 4$ \\
\hline$"$ & $8 \mathrm{~kg}$ & $"$ & $78 \pm 4$ & $77 \pm 6$ \\
\hline ソルゴー & $2 \mathrm{~kg}$ & $"$ & $136 \pm 5$ & $88 \pm 15$ \\
\hline$"$ & $4 \mathrm{~kg}$ & " & $129 \pm 4$ & $69 \pm 12$ \\
\hline エンバク & $4 \mathrm{~kg}$ & 9月 & $60 \pm 2$ & $70 \pm 2$ \\
\hline$" 7$ & $8 \mathrm{~kg}$ & $"$ & $62 \pm 3$ & $72 \pm 10$ \\
\hline ソルゴー & $2 \mathrm{~kg}$ & $n$ & $115 \pm 3$ & $63 \pm 2$ \\
\hline$n$ & $4 \mathrm{~kg}$ & $"$ & $120 \pm 11$ & $61 \pm 1$ \\
\hline
\end{tabular}

注） 8 月： 8 月上旬, 9 月：9月上旬
表 3 遮光の程度と最高, 最低気温較差の差異 （鹿児島，1974年）

\begin{tabular}{|c|c|c|c|c|c|c|}
\hline & & 月 16 & & & 月 22 & \\
\hline 処理別 & 最高 & 最低 & 較差 & 最高 & 最低 & 較 差 \\
\hline 対 照 & $\begin{array}{r}15.8 \\
(0)\end{array}$ & $\begin{array}{r}-4.5 \\
(0)\end{array}$ & $\begin{array}{r}20.3 \\
(0)\end{array}$ & $\begin{array}{r}11.5 \\
(0)\end{array}$ & $\begin{array}{r}-6.0 \\
(0)\end{array}$ & $\begin{array}{r}17.5 \\
(0)\end{array}$ \\
\hline $\begin{array}{l}40 \% \\
\text { 遮 光 }\end{array}$ & $\begin{array}{r}14.3 \\
(-1.5)\end{array}$ & $\begin{array}{r}-4.5 \\
(0)\end{array}$ & $\begin{array}{c}18.8 \\
(-1.5)\end{array}$ & $\begin{array}{c}10.8 \\
(-0.7)\end{array}$ & $\begin{array}{r}-6.0 \\
(0)\end{array}$ & $\begin{array}{r}16.8 \\
(-0.7)\end{array}$ \\
\hline $\begin{array}{l}60 \% \\
\text { 遮 光 }\end{array}$ & $\begin{array}{c}14.0 \\
(-1.8)\end{array}$ & $\begin{array}{r}-4.5 \\
(0)\end{array}$ & $\begin{array}{r}18.8 \\
(-1.8)\end{array}$ & $\begin{array}{c}12.0 \\
(+0.5)\end{array}$ & $\begin{array}{r}-6.0 \\
(0)\end{array}$ & $\begin{array}{r}18.0 \\
(+0.5)\end{array}$ \\
\hline $\begin{array}{l}80 \% \\
\text { 遮 光 }\end{array}$ & $\begin{array}{r}11.5 \\
(-4.3)\end{array}$ & $\begin{array}{r}-4.5 \\
(0)\end{array}$ & $\begin{array}{r}16.0 \\
(-4.3)\end{array}$ & $\begin{array}{r}9.8 \\
(-1.7)\end{array}$ & $\begin{array}{r}-6.0 \\
(0)\end{array}$ & $\begin{array}{r}15.8 \\
(-1.7)\end{array}$ \\
\hline $\begin{array}{c}96 \% 0 \\
\text { 遮 光 }\end{array}$ & $\begin{array}{r}12.0 \\
(-3.8)\end{array}$ & $\begin{array}{r}-4.5 \\
(0)\end{array}$ & $\begin{array}{c}16.5 \\
(-3.8)\end{array}$ & $\begin{array}{r}11.0 \\
(-0.5)\end{array}$ & $\begin{array}{r}-6.0 \\
(0)\end{array}$ & $\begin{array}{r}17.0 \\
(-0.5)\end{array}$ \\
\hline
\end{tabular}

注：（）は対照区との較差

一 1974 年一

\begin{tabular}{|c|c|c|c|c|}
\hline \multirow{2}{*}{ 処 } & \multirow{2}{*}{ 理 } & \multirow{2}{*}{ 別 } & \multicolumn{2}{|r|}{ 丈 $(\mathrm{cm})$} \\
\hline & & & 11月22日 & 12 月 22 日 \\
\hline エンバク & $2 \mathrm{~kg}$ & 8 月 & $58 \pm 6$ & $67 \pm 10$ \\
\hline " & $4 \mathrm{~kg}$ & $"$ & $56 \pm 4$ & $66 \pm 9$ \\
\hline$n$ & $2 \mathrm{~kg}$ & "刈 & $65 \pm 6$ & $67 \pm 5$ \\
\hline$n$ & $4 \mathrm{~kg}$ & $\Rightarrow$ 刈 & $63 \pm 4$ & $69 \pm 4$ \\
\hline$" 7$ & $2 \mathrm{~kg}$ & 9 月 & $42 \pm 4$ & $49 \pm 2$ \\
\hline$"$ & $4 \mathrm{~kg}$ & $" \prime$ & $44 \pm 2$ & $48 \pm 2$ \\
\hline$"$ & $2 \mathrm{~kg}$ & $" x_{I}$ & $41 \pm 2$ & $48 \pm 3$ \\
\hline$"$ & $4 \mathrm{~kg}$ & $n$ 刏 & $44 \pm 3$ & $48 \pm 2$ \\
\hline
\end{tabular}

注） 8 月：8月下旬, 9 月：9月下旬

一.1975 年一

\begin{tabular}{|c|c|c|c|c|}
\hline \multirow{2}{*}{ 処 } & \multirow{2}{*}{ 理 } & \multirow{2}{*}{ 別 } & \multicolumn{2}{|r|}{ 丈 $(\mathrm{cm})$} \\
\hline & & & 11月 5 日 & 12月 1 日 \\
\hline エンバク & 8月 & $30 \mathrm{~cm}$ & $53 \pm 8$ & $63 \pm 1$ \\
\hline$"$ & $\pi$ & $40 \prime$ & $54 \pm 5$ & $63 \pm 5$ \\
\hline$n$ & $n$ & 30 刈 & $53 \pm 7$ & $60 \pm 1$ \\
\hline$"$ & $n$ & 40 XI & $48 \pm 9$ & $59 \pm 1$ \\
\hline$"$ & 9 月 & $30 \mathrm{~cm}$ & $48 \pm 8$ & $62 \pm 2$ \\
\hline$n$ & $n$ & $20 "$ & $49 \pm 11$ & $64 \pm 2$ \\
\hline$"$ & $"$ & $30 x$ & $48 \pm 12$ & $62 \pm 2$ \\
\hline$n$ & $"$ & 20 刏 & $48 \pm 9$ & $60 \pm 3$ \\
\hline
\end{tabular}

注） 8 月：8月下旬, 9 月：9月中旬 
に差がなかったが、ソルゴー草生区の場合は初霜による 枯死とその後の強風による腰折れのため，12月 3 日は折 れた位置の高さであり，この状態では防止効果は低下し た。1974年にはは種期により差がみられ，9月下旬は種 のエンバク草生の草丈 40 ～ $50 \mathrm{~cm}$ では被覆の効果は低く なり,また 8 月下旬は種です刈り込み区は $70 \mathrm{~cm}$ の草丈 はあるものの，十分幼茶樹を包被する状態ではなく，こ のため効果は低下した。

1975年は，エンバク草生の 8 月下旬は種区及び 9 月中 旬は種では，いずれる60〜 $65 \mathrm{~cm}$ の草丈であったが，8 月下旬は種でるは種量の少ないものや，刈り込み区では 防止効果は劣った。9月中旬は種区の場合草丈は十分で あるが品種間に差がみられ，白たかみどりでは防止効果 が得られたが，同じような包被の条件ですやえほでは効 果が少った。一方クロタラリアの場合の草丈は $70 \mathrm{~cm} て ゙$ あったが，クロタラリア自体の地際部に裂傷を起して枯 死し，草生の効果は期待できなかった。

また草生の包被程度を株元付近の日射量でみると次の と怙りであった。初霜以降枯死するソルゴー草生区にお いては，エンバク草生区の 日平均照度 30lx であるのに 対し，140 Ix でエンバクの 20\%の遮光にしか過ぎず，こ のために防止效果は低下したるのと思われる。さらに 1974〜1975 年にかけてのエンバク草生内の日射量から繁 茂状態を推定してみると図7亿示すと扮りである。両年 之も無処理区が日平均日射量が $156 \sim 175 \mathrm{cal} / \mathrm{cm}^{2}$ である のに対して, 効果の高い 8 月下旬は種の $4 \mathrm{~kg} \cdot 30 \mathrm{~cm}$ は 40〜60で無処理区の 25〜35\%となり，他のエンバク炕 理区の日平均日射量は $70 \sim 103 \mathrm{cal} / \mathrm{cm}^{2}$ で無処理区の 40 〜70\%であった。以上のことから草生状態としては，単
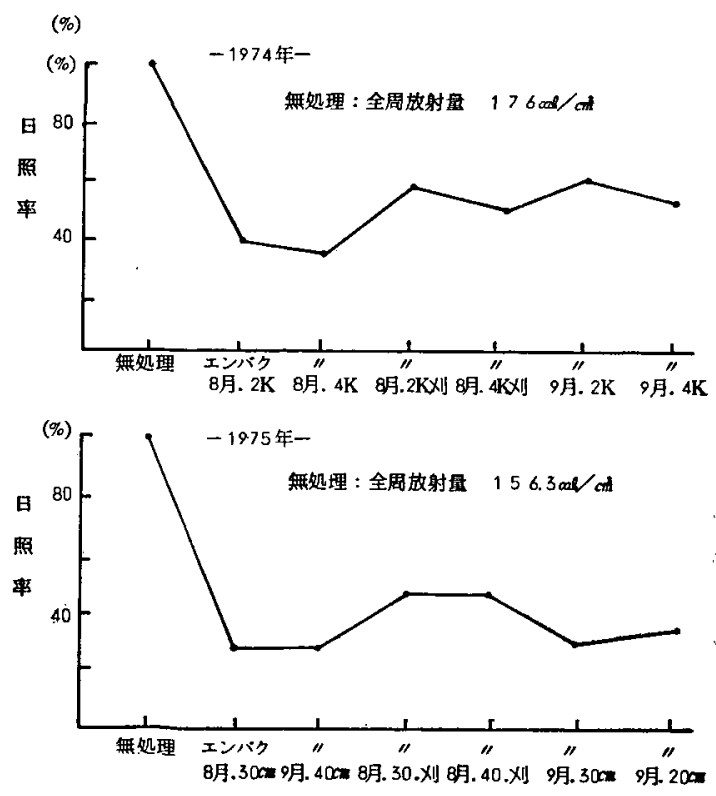

図 7 裂傷型凍害前後の日射量の差異
に草丈だけでなく幼茶樹を完全に包被することが必要 でこのときの株元付近を $30 \%$ 程度とする遮光は必要と 思われた。

\section{4 草生茶園の土壊水分の動態}

資材被爱の場合 幼茶樹は蒸散を抑制されるが，草生の 場合は，草による盛んな吸水が幼茶樹の吸水能をある程 度制御し，これが裂傷型凍害の軽減に役立っていると推 察される。すなわち，草生期間中の土壌水分は処理間に 差がみられたが，その年次別の裂侮発生時の草生別土境 $\mathrm{pF}$ 值は図 8 のと㧍りである。1973 年は11月上旬以降異

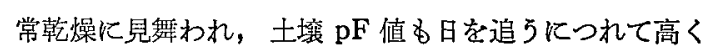
なったが，裂賃発生日に打ける無观理区の $\mathrm{pF}$ 值は 2.31

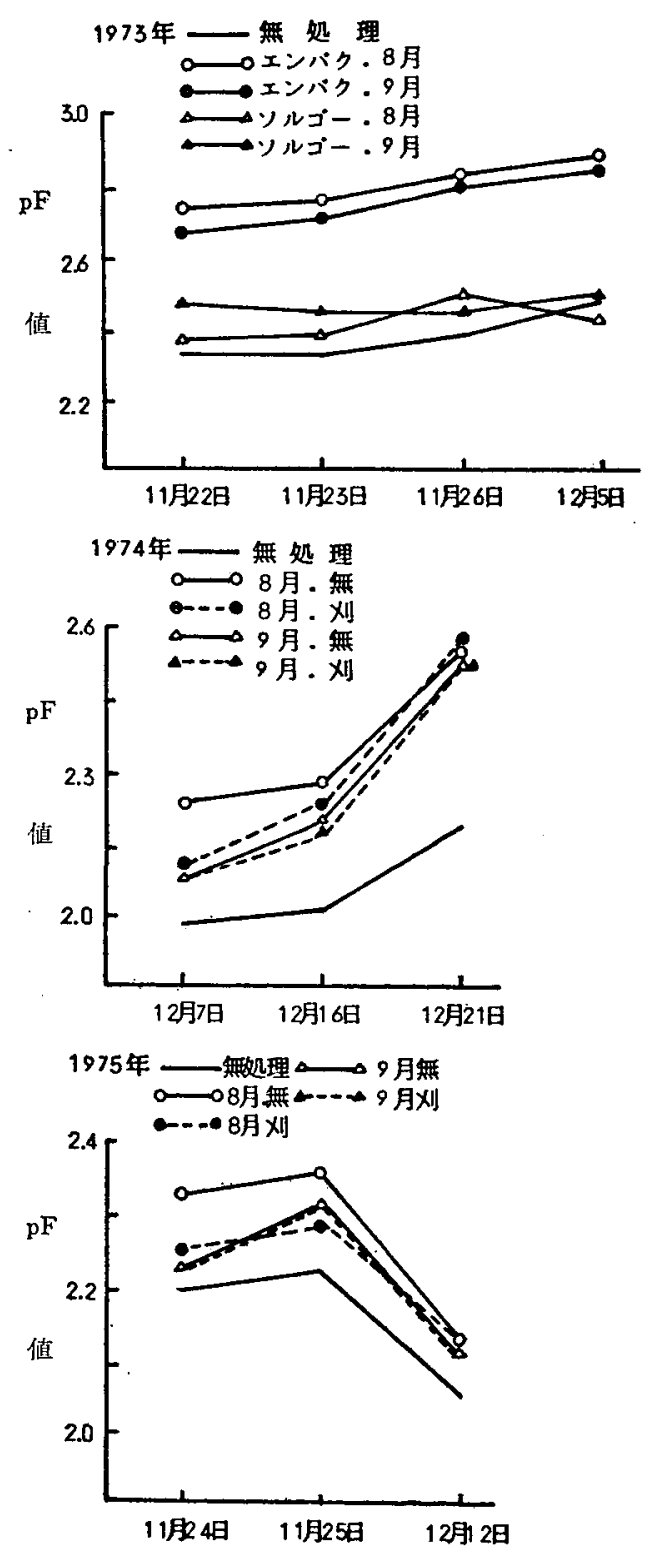

因 8 草生法の裂傷発生日の土壊 $\mathrm{pF}$ 值の差異 
〜2.45であったのに対し，ソルゴー区 2.25〜2.53，エ ンバク区2.60〜2.87 でエンバク区が高位に 推移した。 1974 年は比較的降雨に恵まれたため前年よりる $\mathrm{pF}$ 值は 低く経過したが，䈍処理区 1.96〜2.16，8月は種区2.12 〜2.45，9月は種区 2.12〜2.45 でエンバク区が高く草 生量の多い区汪ぞ高い $\mathrm{pF}$ 值となった。1975 年は気象 81973年溇似し発生日は無処理区 2.04 2.22，8月は 種区 2.10〜2.35，9 月は種区 2.08〜2.30でいずれる刈 り込みによって $\mathrm{pF}$ 值はわずかに低くなった。このよ 5 に草生区の土壤 $\mathrm{pF}$ 值は高めに推移したが、ソルゴー, クロタラリア草生等の場合は初箱以降枯死するので，無
処理に近い状態であろうと思われる。

一方，土壤の得分との関係の場合，資材によるトンネ ル被覆処理下での土墡溶液濃度の動態は無処理々変わら ないと思われる。しかし草生処理のらち，特に初冬以降 す繁茂するエンバクなどでは，は種前の基肥はもちろん のこと, その後も2〜3回 (N $4 \mathrm{~kg} / 10 \mathrm{a})$ の追肥を施 さないと前項で示した草生状態に達し得ない。図 9 に示 した時期的な土壤の EC 值の測定の結果では, エンバク 草生区が無処理区よりる常に低位に推移していたが，こ のことはエンバク草生は土壤中の N濃度を低下させて閭 接的に裂傷型凍害の㪕減に役立っていると思われる。

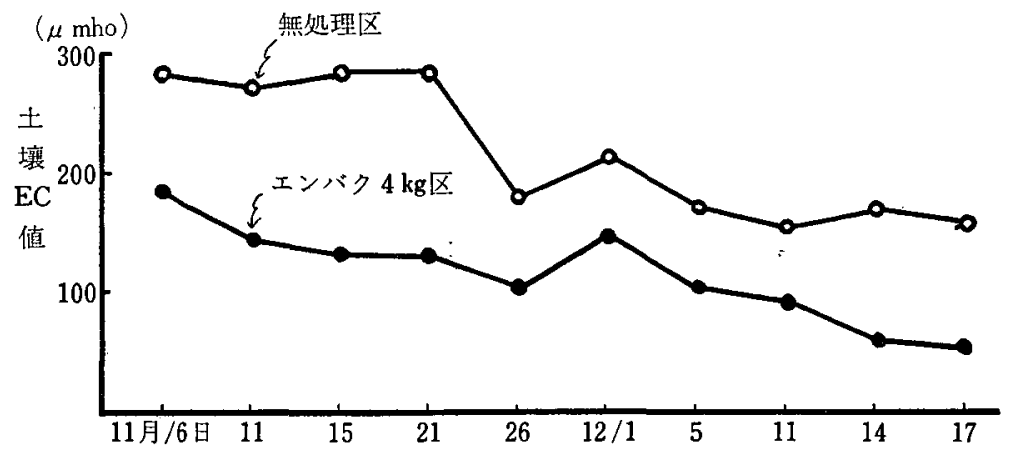

図 9 草生栽培における時期的土壞 EC の動態 (宮崎, 1975年)

\section{5 裂傷発生後の茶樹の生育}

草生及び資材被覆処理開始以降, 裂傷型凍害発生時ま での奻茶樹の生育は，各处理区ともあまり差がなく活湮 順調な生育を示したが，前述のよ5にシルバーポリトウ では遮光度が強いため裂賃発生以前に枯死した。裂傷発 生以降は翌年 3 月上旬まで草生や資材拠理区とるに除去 は行わなかった。従って1〜2月の厳寒期をそのままで 越せたわけであるが，無処理区よりすむしろ良好な生育 状況を示するのが多く，遮光の 悪影響はみられなかっ

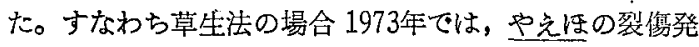
生が無処理区98\%，ソルゴー区 50〜75\%，エンバク区 0 〜196゙あったが，翌年6月中旬までの生存状況をるる と無処理区が17\%，ソルゴー区53〜77\%，エンバク区 83 〜96\%とエンバクが高い生存率を示した。ただ $8 \mathrm{~kg}$ 種区では過繁茂による強い遮光之倒伏により，幼茶樹の 生育をやや阻害する面もみられて生存率を低める結果上 なった。里たかみどりでは無処理区の裂傷発生が 27\%， 処理区0\%であったが，生存率では各処理区とす94\%を 超える状況であった。

1974年では，や它活の裂賃発生は無処理 89\%，エンバ ク草生区は 0 ４5\% となり，生存率は無处理区 $60 \%$ に対 し，エンバク 8 月は種区が 97\%以上とすぐれ，9月は種 区では 89〜93\%と8月は種区より若干劣った。

旦たかみどりでは裂傷の発生はなく，いずれる100\%
の生存率となった。さらに 1975年をみるとや充压の場合 裂伤発生が無処理区 99\%，エンバク草生区 0 98\%であ り，このため無処理区の生存は皆無となり，エンバク草

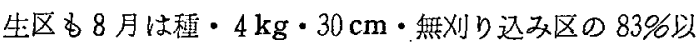
外は全て $55 \%$ 以下となり前 2 力年に比し著しく低下し た。ツたかみどりの場合無処理区 93\%，エンバク草生区

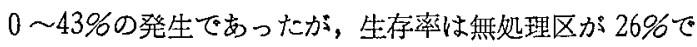
あったのに対しエンバク草生区は 87〜100\%と高かった。 このよ5に裂傷型東害の発生が多い処理区は，生存率も 低下する傾向が明らかであった。

一方，資材被覆についてみると，1973年はや立㴗の裂 甥発生が無処理区 95\%，資材処理区44〜95\%であった

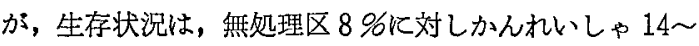
18\%, BB テックス 38〜44\%，こす区 51\%，ピアレス区 59\%となり，かんれいしゃ以外は 40\%を越す状況であっ た。曲たかみどりでは各処理区とも100\%の生存となっ た。1975年の場合や之注の裂傷発生が無処理区 99\%，資 材処理区 95〜100\%であったが，これの生存状況をみる 之無処理区はわずか $8 \%$ \%あり，処理区もこすの $86 \%$ 以 外は 20〜40\%の低い生存摔であった。品たかみどりの裂 甥発生は無処理区 $100 \%$, 資材処理区 19〜84\%であった が, 生存率では無処理区の 61\%に対し他は83〜100\% の高い生存状沉を示した。

このように裂傷型凍害発生後の生存率は, 品種間に打 
いてもまた草生法ならびに 資材被覆法のいずれも裂倁発 生率の低い情ぞ良好であった。しかし一方では草生の場 合裂侮発生は防止でさても，その後の過剩の繁茂と倒伏 により幼茶樹の生育を阻害することも十分考虑しておく 必要があり，また，資材被覆の場合は裂傷防止効果は若 干低下しても笽寒期のトンネル被覆により纳茶樹を保 護し，裂賃部分を治肪する，ある程度の役割を果し裂甥 発生率とは逆に生存率を高める結果となったるのと思わ れた。

\section{4 総 合 考 察}

初霜以降に枯死するソルゴー，クロタラリア等の草種 は，裂倠型凍害極弱のやえほでは，ある程度以下の低温 条件下では十分に防止することができず，降霜後す生育 繁㕠するすのが適当であると思われた。供試した草種の なかでは，エンバクが最も防止效果が高かったが，この 場合は種量が多すぎると過繁茂により茶樹の生育が阻害 されたり，倒伏により茶樹を痛めたり，株元保護が不完 全になる。また逆には種量が少なすぎるとまさむら等に より生育が不均一となり，株元保護が不十分となる。

本試験の結果, $10 \mathrm{a}$ 当たり $4 \mathrm{~kg}$ のは種量が最す適当 と思われた。は種期は 8 月上旬, 8 月下旬ならびに 9 月 上旬ではいずれも効果に差がなく防止率は極めて高い が，9月下旬のは種期では 11 月下旬の裂傷発生時に草丈 が足りず防止は困難であり，また9月中旬は種す的たか

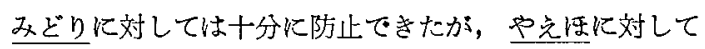
は不十分であった。このことと現地試験結果を加味して は種期をみると，平坦地では 8 月下旬，また山䦭地では これよりは種期を早めた活5が良いと思われた。

8 月下旬は種のなかで過繁茂による幼茶樹への生育影 響を考虑して刈り込及等を実施したが，刚り込んだりは 種位置を拡げたりすると株元が直接保護されず空隍が生 じ冷気がたまって低温の持続が一段と笡しくなり，かえ って裂賃の発生を助長した。

以上のことから 裂㥂の発生防止のための草生状態をみ ると, 茶株付近 (15 20 cmの高さ)の日射量が $50 \mathrm{cal} / \mathrm{cm}^{2}$ 程度で無被覆状態の日射量の約 $30 \%$ となる遮光で，乙か
す草丈は幼茶樹の高さ以上にあって, 完全に包被した状 態でなければならないと思われ，笹沿によるスギ苗の巣 植の効果はこれを裹付けている。またエンバクの草生に よる幼茶樹の完全包被は，樹の生育に対してそれほど恶 影響を及ぼしていいことがわかった。しかし，できる

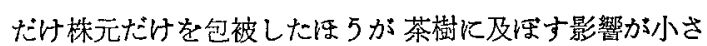
いと考兄られるため，幼茶樹の生育量を大きくした注う 加好屯しい。

一方，資材被覆処理下での裂傷発生は，品種によって 差がみられ裂傷型凍害抵抗性極弱のや之活に対しては全 ての資材も防止效果は劣るよ5であったが，里たかみど 可のらな抵抗性弱の品種に対しては，かなりの效果を みせて品種間差を明確に示した。資材別では，こものト ンネル被覆が最も良く BBテックス，タフベル，かんれ

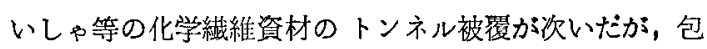
被による処理法等は防止効果は低くなった。また，これ ら資材の裂傷発生時の保温効果は低温の程度によって相 違したが，3カ年間を通じてこもが最も良く，次いでBB テックス等であり，かんれいしゃ等は若干劣る傾向がみ られた。このように各資材における保温効果は材犋から

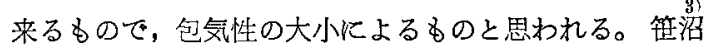
はスギの苗木の凍害防止を検討するなかで，よしず，か んれいしゃ被緮内の気温の日変化を調べよしずのほ5が 日較差は小さく断熱効果は大きいとしている。すた本処 理に括讨る保温効果はこも，BBテックス，タフベル， かんれいしゃとなって拐り，これが裂賃発生に差を生じ たものと思われた。そして各資材の冬季間全期にわたる トンネル被覆が幼茶樹に与える影響は，翌年資材除去 （3月上旬）までなんら生育に支障はるたらさなかった。 草生や凟材被覆に怙ける墈場での障害発生のなかで, 両者とも保温により夜間の急激な低温から幼茶樹を保護 して裂䂓を防止あるいは軽減する共通点が指摘できた。

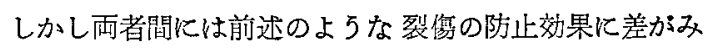
られ，資材被覆処理が少る結果となったが，これの要因 は次の点が考党られよ5。一つには保温の差であるが， 表 5 に示したよ5に裂賃発生日のこもとエンバク草生間 の最低気温は， $0 \sim 0.8^{\circ} \mathrm{C}$ の差でしかなかったのに対し

表 5 裂甥発生日に括ける資材と草生の父温の差異

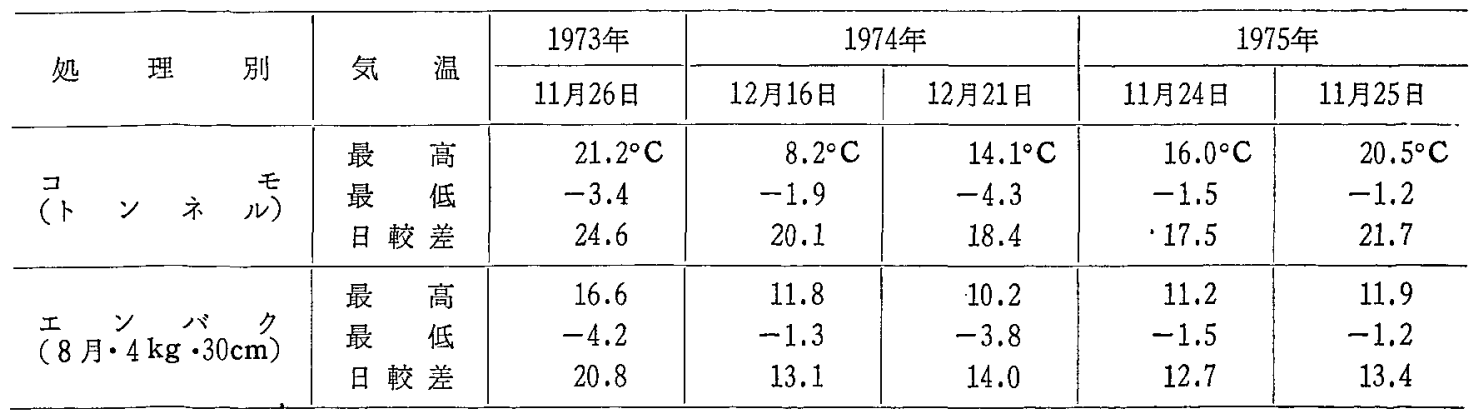


昼間の最高気温は, $3.9 \sim 8.6^{\circ} \mathrm{C}$ とエンバク草生が 3 カ 年とす低くなって日較差が小さかったこと。二つには, 土壤水分の制御の面であるが，両者とも幼茶樹全体を完 全に被覆する条件下にあったが，こすの場合エンバク草 生よりは幼茶樹との水分競合は小さいこと。三つ目に は，幼茶樹の吸肥の差異もあろう。茶試枕崎支場の結亲 によると裂傷の発生時には土壤 N濃度は高くない性らが 好ましく，また大城らの施肥法の検討結果です秋肥の施 用を 8 月上旬をでか，あるいは八ードニングの進んだ 11 月に入ってから行党ば，慣行の 9 月上旬施肥に比べ酎凍 性は增し裂傷の発生は軽減されるとしているが，特にエ ンバクのように投肥生長の盛んなものは，幼茶樹との吸 肥の競合により資材被覆に比べ境 Nが低濃度に陥いり 易いことも大きい要因であろらと思われた。

このように 幼茶樹の幹の裂賃発生防止法のなかで効果 の高いエンバク草生の場合, 保温, 土壤水分制御および 土壤Nの制御が大きい要因として考えられた。

$$
5 \text { 摘 要 }
$$

暖地の幼茶樹记発生する 裂傷型凍害の発生防止法とし て草生法ならびに資材被覆について 1973〜1975年にわた り試験しだ。

1）チャの幼木を簡易に被覆する草生や資材利用法で は，ともに裂傷の発生時に 夜間の気温低下を抑制し，裂 傷型凍害を軽減する効果がみられたが，供試品種の抵抗 性の程度により裂傷発生率には差が認められた。

2）草生法では，初霜以降低温により枯死しないエン バクのような草種の効果が高かった。

3）エンバク草生の効果は，裂傷発生時期江幼茶樹全 体を被覆 (日射量 $40 \sim 60 \mathrm{cal} / \mathrm{cm}^{2}$ ) できる5 5 亿繁茂さ せるとき最も良かった。このためは種期は，8月下旬が 適期で，は種位置は株の禹侧 $30 \mathrm{~cm}$ の距離で，は種量は $4 \mathrm{~kg} / 10 \mathrm{a}$ が良かった。

4）資材被覆では BBテックス，タフベル，かんれい しゃの効果が認められたが，こすの効果には及ばなかっ た。

5）エンバク草生は，資材被覆法より效果が高かった が，その理由として茶株内の最高気温の抑制, 土㙥水分 の制御抒よび N肥料の吸収に対する茶樹との競合効果な が考宎られる。

\section{6 引用文 献}

1）鳥屋尾忠之, 上野貞一, 家弓実行, 平川今夫, 田 原 誠, 松下 繁, 武田善行: 茶研報, 資料 No. 4, 23 30 (1979).

2）笹沼たつ, 高松亀久松, 本木 茂：日林誌，No.
49, 398 401, (1967).

3）笹沼たつ：日林誌，No. 53，22〜25 (1971).

4）弓家昭一, 樋口義則, 徳永保利, 楠原俊秋: 宮研 報, No. 11, 31 47 (1977).

5）農林省茶試视崎支場茶樹第 2 試験成績聙：昭和 49 年, $64 \sim 67$ (1974).

6）大城光高, 獄崎 亮, 岡本信義 : 茶技研䄀要, 17 (Feb. 1974).

\section{Summary}

Covering methods with some kinds of grasses and chemical textures were studied from 1973 to 1975 for the effectiveness in preventing the bark splitting injury that is a kind of cold injury caused by frost and is mostly found in young tea plants grown in warm regions.

1. It was proved that all the covering methods protected young tea plants from being exposed to extremely low temperature in occurrence time and consequently reduced the damage of the bark splitting injury.

2. The type of grasses that are tolerable to a low temperature, such as oats, showed greater effect than sorghum or crotalaria which is tender to a low temperature.

3. The covering method with oats showed great effect in the case that they had perfectly covered the young tea plants, when the amount of insolation was $40-60 \mathrm{cal} / \mathrm{cm}^{2}$, before the occurrence season of the bark splitting injury.

The best result was obtainded in the case that the seeds fo about $4 \mathrm{~kg} / 10 \mathrm{a}$ had been sowed in belt on both sides about $30 \mathrm{~cm}$ apart from a row of the tea plants in late August.

4. Straw mat and chemical textures (BB-tex, Tuffubel and cheesecloth) used as covering materials were also effective to prevent the injury but the covering effect of the chemical textures was smaller than that of the straw mat.

5. The covering method with oats showed greater effect than any other methods probably because the method kept low the maximum air temperature under tea plants' crown and controlled the supply of moisture and nitrogen in soil to tea plants through competition.

(Jan. 26, 1978) 